ISSN (print): 2706- 6908, ISSN (online): 2706-6894

Vol.15 No.1 Mar 2020

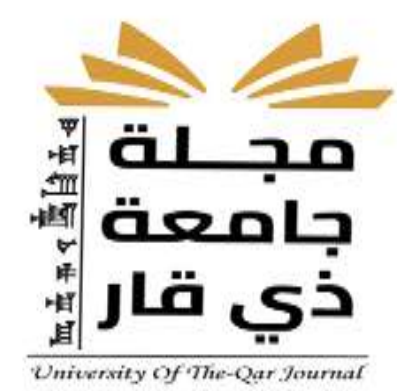

\title{
The effect suggested exercises to develop some motor abilities and learning some free skills in the rhythmic gymnastic of female students
}

\author{
M.M Suhair Rahman Salman \\ College of Physical Education and Sports Science \\ S4.sport@yahoo.com
}

https://doi.org/10.32792/utq/uti/vol15/1/1

\begin{abstract}
:
The aim of the study is to prepare suggested exercises for the development of some motor abilities and learn some free skills in the rhythmic gymnastic for the first stage students. The Faculty of Physical Education and Sports Sciences / Dhi-Qar University. The research community consisted of 40 students. (4) students, and the number of female (2) students, and participants in the pilot experiment and the number (10) students, The remaining number is (24) students divided into two groups of control and experimental, the researcher came to a set of conclusions, the most important of which is the use of proposed exercises aimed at the nature of fun and competition used on the experimental group has directly and significantly in performance, which led to the improvement and development of motor abilities And the improvement in the performance of students in the post-test, there were significant differences between the pretest and the remote and for the benefit of the post-test and the experimental group, In addition to the performance of the experimental exercises, the study showed that there were significant differences in the post-test between the experimental group and the control group and in the interest of the experimental group in the development of motor characteristics (agility, flexibility, balance, compatibility). The proposed exercise has developed better than the traditional curriculum.
\end{abstract}

Keywords: The rhythmic gymnastic, Skills, Exercises, Kinetic abilities, Developm 


\section{University of Thi-Qar Journal}

ISSN (print): 2706- 6908, ISSN (online): 2706-6894

Vol.15 No.1 Mar 2020

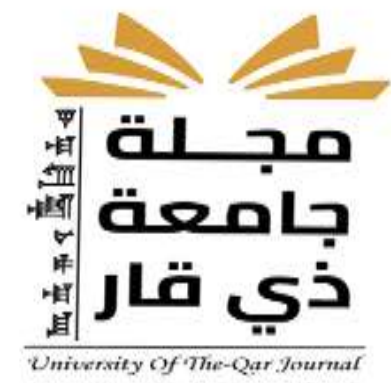

\subsection{Research introduction and its importance:}

It was and still preparing physical education students is one of the most important goals that physical education colleges seek to achieve, and choosing the appropriate method for performance has a great impact in achieving the goals of the game that are taught even though the methods differ according to the different topics and the level of difficulty of the games, as any scientific progress in performance In various games or sporting events it occurs as a result of various modern means and methods in the educational process.

The sport of rhythmic gymnastics is one of the individual games with multiple skills that work to develop neuromuscular compatibility in addition to its work in improving posture, the physical and kinematic abilities that a person acquires from the surroundings or are present in it, as it leads to the building of an integrated body physically and dynamically that qualifies it to assume the tasks of work, so the sport of rhythmic gymnastics needs requirements in addition to basic elements related to the nature of the performance and the type of instrument used, It is one of the sports that women are most affected by it, as they actively contribute to building them physically, intellectually and physically in order to be qualified in carrying out their duties as required, and this game combines these motor abilities to reach optimal performance, so the importance of research lies in the use of cardio exercises to develop some Physical and kinematic abilities and learning some rope skills in rhythmic gymnastics on the third stage students to help lay the correct scientific foundations for this game and the educational process in this regard.

\subsection{The research problem:}

That the development in all areas of learning requires the use of modern methods and methods, whether educational or training, that have a positive impact on developing skills in a tangible way. In particular, and through the researcher's follow-up to the lesson of rhythmic gymnastics because it is teaching this subject, I noticed that there is a problem that most students face difficulty in performing some of your rhythmic gymnastics skills, and the researcher believes that the reason for this is the weakness of physical and movement abilities that appeared through their performance of some skills. The first phase begins its practice session after several weeks from the official working hours for the rest of the stages, and as we know that the movement capabilities of this sport need sufficient time to develop, especially since most of the accepted students are a group that did not seriously practice sports in the past, so the researcher decided to use some Suggested exercises to develop some motor abilities and learn some free skills in rhythmic gymnastics with less time and less effort.

\section{3. research aims :}




\section{University of Thi-Qar Journal}

ISSN (print): 2706- 6908, ISSN (online): 2706-6894

Vol.15 No.1 Mar 2020

1.3.1.Preparing the exercises suggested to develop some movement abilities and learn some free skills in rhythmic gymnastics for female students.

1.3.2. Learn about the effect of exercises suggested to develop some movement abilities and learn some free skills in rhythmic gymnastics.

1.3.3. Identify the significance of the differences in the level of learning some movement abilities and learning some free skills in rhythmic gymnastics between the two research groups (experimental and control) in the post-tests.

\subsection{Research Hypotheses:}

1.4.1. The presence of significant statistical differences between the pre and post tests for the control and experimental groups in favor of the post tests.

1.4.2. The presence of significant statistical differences between the control and experimental groups in the post-tests.

Research methodology and field procedures:

\subsection{Research Methodology:}

There are many approaches that are used in scientific research, and in order to reach the research objectives, the researcher used the experimental method with the design of the two equal groups due to its suitability to the nature of the research.

\subsection{Research community and its sample:}

The research community, represented by the first stage students / College of Physical Education and Sports Sciences - Dhi Qar University for the 2016/2017 academic year, and their number (40) students divided into two classes (A - B) were identified, and the researcher excluded a number of the female students for the following reasons:

* (2) A postponed female student * (4) female students who were absent from taking the exam * (10) female students for an exploratory experiment sample, so that the final number of the research sample would be (24) students from both divisions, and by (12) female students from each class, who would constitute $(60 \%)$ From the original community, they were divided into two groups (control and experimental), where the students of Division (A) represented the control group and the students of Division (B) represented the experimental group, and the researcher adopted the random method and the method of lottery in all stages of the evaluation.

\subsubsection{Sample Equivalence:}

For the purpose of ascertaining the equivalence of the two research sample members in (movement abilities and some free skills), the researcher conducted a parity test using the T-test, and Table (3) shows the parity of the sample members. Table (3) It shows the results of the equivalence of the control and experimental 


\section{University of Thi-Qar Journal}

ISSN (print): 2706- 6908, ISSN (online): 2706-6894

Vol.15 No.1 Mar 2020

groups with the motor abilities and some free skills the subject of research using the T-test Statistical treatment Variables The experimental group and the control group The value (T) Computed significance

\begin{tabular}{|c|c|c|c|c|c|c|}
\hline \multirow[b]{2}{*}{$\begin{array}{c}\text { الدلالة } \\
\text { indication }\end{array}$} & \multirow{2}{*}{$\begin{array}{c}\text { قيمة } \\
\text { ( T ) } \\
\text { Values } \\
\text { (T) } \\
\text { Calculated }\end{array}$} & \multicolumn{2}{|c|}{ الـــموعة الضــــابطة } & \multicolumn{2}{|c|}{$\begin{array}{c}\text { الــجمو عة التجـــريبية } \\
\text { The experimental group }\end{array}$} & \multirow{2}{*}{$\begin{array}{c}\text { المعالجة الإحصائية } \\
\text { Statistical treatment } \\
\text { Variables }\end{array}$} \\
\hline & & $\begin{array}{l}(\varepsilon \pm) \\
( \pm y)\end{array}$ & $\begin{array}{c}(\omega-) \\
(-x)\end{array}$ & $\begin{array}{l}(\varepsilon \pm) \\
( \pm y)\end{array}$ & $\begin{array}{c}(w-) \\
(-x)\end{array}$ & \\
\hline $\begin{array}{c}\text { غير دال } \\
\text { non-significant }\end{array}$ & 0.257 & 2.19 & 2.20 & 1.42 & 2.35 & 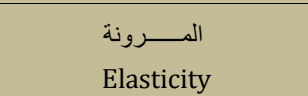 \\
\hline $\begin{array}{c}\text { غير دال } \\
\text { non-significant }\end{array}$ & 1. 049 & 0.967 & 15.50 & 0.825 & 14.87 & الــــــاقة \\
\hline $\begin{array}{c}\text { غير دال } \\
\text { non-significant }\end{array}$ & 1.032 & 1.82 & 3.50 & 1.24 & 2.50 & التـــــــوازن Equilibrium \\
\hline $\begin{array}{c}\text { غير دال } \\
\text { non-significant }\end{array}$ & 0.500 & 1.93 & 10.85 & 3.02 & 10.45 & 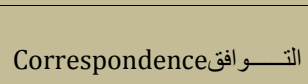 \\
\hline $\begin{array}{c}\text { غير دال } \\
\text { non-significant }\end{array}$ & 1,199 & 1,033 & 1,792 & 1,010 & 1,292 & $\begin{array}{l}\text { قفزة القطة } \\
\text { Cat jump }\end{array}$ \\
\hline $\begin{array}{c}\text { غير دال } \\
\text { non-significant }\end{array}$ & 0,061 & 0,831 & 1,542 & 0,854 & 1,563 & $\begin{array}{l}\text { Scissors jump } \\
\text { Sciajة القصص }\end{array}$ \\
\hline $\begin{array}{c}\text { غبر دال } \\
\text { non-significant }\end{array}$ & 0,054 & 0,806 & 2,188 & 0,982 & 2,208 & $\begin{array}{l}\text { وثبة الخطوة } \\
\text { The step dart }\end{array}$ \\
\hline
\end{tabular}

The tabular $\mathrm{T}$ value under the degree of freedom (22) and the level of significance $(0.05)$ is $(1,717)$

It is clear from Table (3) that the value of (T) calculated for all research variables is less than the tabular value of $(\mathrm{T})$ of $(1,717)$ under the degree of freedom $(22)$ and the level of significance (0.05), which indicates that there are no differences between the two groups. This indicates the equivalence of the two research groups in all variables.

\subsection{Devices, tools and auxiliary means:}

For the purpose of achieving the field research procedures, the following devices, tools and auxiliary means have been used:

Equipment: - (Sony) video camera, ((JVC)) television projector, tape recorder, medical scale.

Tools: - ( 2 ) stopwatches, (4) chairs, (10) straps, (4) sign, (2) ropes, 10 colored cardboard in various geometric shapes, a metal tape of (2) meters long to measure 


\section{University of Thi-Qar Journal}

ISSN (print): 2706- 6908, ISSN (online): 2706-6894

Vol.15 No.1 Mar 2020

the length, chalk, a whistle, a leather tape of (50) meters for measuring distances.Means: - Observation and experimentation, a questionnaire form to survey the opinions of experts, the arbitration committee, a personal interview.

\section{3 . 4 Field research procedures}

\subsubsection{Determination of motor abilities:}

With the aim of determining the priority mobility abilities in movement performance, which are required to be developed for the female students, the researcher prepared a questionnaire to survey the opinions of (10) experts and specialists in the fields of teaching methods, kinesthetic learning, and rhythmic gymnastics, (Appendix 3), and in light of the results of that questionnaire, the abilities obtained were excluded At a rate less than $70 \%$.

\subsection{2 plastic (formation ) performance evaluation:}

The researcher was approved in evaluating the plastic(formation) performance on those with experience and competence in gymnastics, where the committee consisted of five referees $*$ and the final degree of performance was of (10) degrees in which it depended on the apparent construction of the skill and was extracted after deleting the highest and lowest degree and then extracting the final degree from the middle The arithmetic for the remaining three grades, for the purpose of evaluating the technical performance of each student, a ready, standardized form for the three skills was chosen, Appendix (5).

\section{Nomination of tests for motor abilities:}

After determining the motor abilities in light of the results of the questionnaire form Appendix (1), the researcher prepared another form, Appendix (2), to nominate the most appropriate tests that measure motor abilities, and the form was presented to experts and specialists in the specializations of tests, measurement, motor learning and teaching methods (whose names are explained In Appendix (1) to nominate the most appropriate tests that measure movement abilities.

\section{5 The exploratory experience}

For the purpose of identifying the difficulties that may arise during the implementation of the main experiment, the researcher conducted an exploratory experiment on a sample of (10) students on Monday, 11/28/2016.

The purpose of conducting the pilot experiment was as follows:

1. Ensure the validity of the devices and tools used.

2. Training of the assisting team members on how to carry out the tests and use and record the results 


\section{University of Thi-Qar Journal}

ISSN (print): 2706- 6908, ISSN (online): 2706-6894

Vol.15 No.1 Mar 2020

3 . Finding the scientific weight of the candidate tests in terms of consistency, validity and objectivity.

\subsection{The scientific basis for the tests used}

\subsection{Stability of the tests:}

In order for the researcher to verify the stability of the tests, the researcher used the test method and re-test after (7) days, and through the simple correlation coefficient (Pearson) between the degree of application of the first test and the degree of application of the second test to find out the coefficient of stability, and it is noticed that all the values of the calculated correlation coefficient were greater than The value of the tabular correlation coefficient of (0.632) at a degree of freedom (8) and a level of significance (0.05), which indicates the presence of high stability, and as shown in Table No. (6).

\section{3 .6 . 2 Test validity:}

To ensure the validity of the tests, the researcher used the self-validity coefficient, which is equal to the reliability coefficient, and after applying the law of self-validity to all the tests under study, it was found that the tests have high selfvalidity scores, and as shown in Table (6).

\subsection{Objectivity of the test:}

The researcher calculated the test objectivity coefficient, where the tests were conducted under the supervision of impartial arbitrators * taking into account the stabilization of the conditions and the method of conducting the tests themselves.

After that, the results were collected and statistically treated by the simple correlation coefficient (Pearson) between the results of the sample members for each of the arbitrators to express the objectivity coefficient.

\subsection{Pre-exams:}

The tests and measurements are considered means of evaluation, diagnosis and guidance, and in light of this concept, pre-tests of the kinetic capabilities of the research sample were conducted on Sunday 4-7 / 12/2016, at nine o'clock in the morning for the experimental and control groups, by three days, as follows:

The first day: tests the movement capabilities (agility and flexibility) for the experimental and control groups.

The second day: tests the movement abilities (balance and compatibility) for the experimental and control groups.

The third day: tests the basic skills of rhythmic gymnastics for the experimental and control groups.

The conditions related to the tests, such as location, time, devices and tools used and the method of carrying out the tests, have been taken into consideration, with the aim of trying to find the same conditions as possible in the post-tests. 


\section{University of Thi-Qar Journal}

ISSN (print): 2706- 6908, ISSN (online): 2706-6894

Vol.15 No.1 Mar 2020

\subsection{Educational Curriculum:}

In order to ensure the validity of the scientific foundations followed in the main section of the teacher's regular educational curriculum, the main section was finalized as it included (8) educational units *, for a period of (8) weeks and at the rate of one unit per week every Sunday according to the schedule for the two groups, where the group takes Experimental the new curriculum prepared by the researcher. As for the control, the teacher takes the usual curriculum, and the educational curriculum extended from 11-12-2016 until 1-30-2017, as the total time for the curriculum was (480) $\mathrm{m}$, and the share of the main section of it was (60) $\mathrm{m}$ per week out of (90) m, appendix (4).

\section{3 .9 Dimensional Tests:}

After completing the application of the proposed approach, the researcher conducted the post-tests for both the experimental and control groups, taking into account the same circumstances. The post-tests were conducted for the period from 01-31-2017 to 02-2-2017, by three days and the same mechanism of pre-tests.

\section{3 .10 statistical methods:}

To treat the results, the researcher used the following statistical methods: -

1. Percentage.

2. Arithmetic mean.

3. Standard deviation.

4. Simple correlation coefficient (Pearson).

5. (T) test for independent samples.

6. (T) test for analog samples.

7. Torsion coefficient.

Presentation, analysis and discussion of results:

1-4 Presentation, analysis and discussion of the results of the test (T. test) for movement characteristics and free skills in the pre and posttest for the experimental and control groups

For the purpose of knowing the significant differences between the pre and posttest of the movement abilities and skills of the experimental group, the researcher used the (T. test) test for the corresponding samples, as shown in Table (7).

It shows the arithmetic mean, standard deviations, and (T) value computed for the pre and posttests of the experimental group in movement abilities and free skills in rhythmic gymnastics. 


\section{University of Thi-Qar Journal}

ISSN (print): 2706- 6908, ISSN (online): 2706-6894

Vol.15 No.1 Mar 2020

\begin{tabular}{|c|c|c|c|c|c|c|c|}
\hline \multirow[t]{2}{*}{$\begin{array}{c}\text { الدلالة } \\
\text { indication }\end{array}$} & \multirow{2}{*}{$\begin{array}{c}\text { قيمة (T) } \\
\text { المحسوبة } \\
\text { Computed } \\
\text { value } \\
\text { (T) }\end{array}$} & \multicolumn{2}{|c|}{$\begin{array}{l}\text { الاختبار البعدي } \\
\text { The post-test }\end{array}$} & \multicolumn{2}{|c|}{$\begin{array}{c}\text { الاختبار القبلي } \\
\text { The pre-test }\end{array}$} & \multirow{2}{*}{$\begin{array}{c}\text { وحدة القياس } \\
\text { measuring } \\
\text { Unit }\end{array}$} & \multirow{2}{*}{$\begin{array}{c}\text { المتغبير/ت } \\
\text { Variables }\end{array}$} \\
\hline & & $\begin{array}{l}\varepsilon+ \\
+Y\end{array}$ & $\begin{array}{l}-\omega \\
X-\end{array}$ & $\begin{array}{l}\varepsilon+ \\
+Y\end{array}$ & $\begin{array}{l}-س \\
X-\end{array}$ & & \\
\hline معنوي & 7.31 & 1.67 & 3.8 & 1.42 & 2.35 & سم & $\begin{array}{c}\text { المرونة } \\
\text { Flexibility }\end{array}$ \\
\hline معنوي & 7.14 & 0.84 & 13.03 & 0.83 & 14.88 & $\begin{array}{c}\text { ثانية } \\
\text { second }\end{array}$ & $\begin{array}{l}\text { الرشاقة } \\
\text { Agility }\end{array}$ \\
\hline معنوي & 8.56 & 2.48 & 6.45 & 1.42 & 2.5 & $\begin{array}{c}\text { ثانية } \\
\text { second }\end{array}$ & $\begin{array}{c}\text { التوازن } \\
\text { Balance }\end{array}$ \\
\hline معنوي & 3.76 & 3.02 & 10.45 & 2 & 5.15 & $\begin{array}{l}\text { ثانية } \\
\text { second }\end{array}$ & $\begin{array}{c}\text { التو افق } \text { Compatibility seconds } \\
\text { Come }\end{array}$ \\
\hline معنوي & 3.91 & 0.23 & 2 & 0.46 & 1.65 & $\begin{array}{l}\text { درجة } \\
\text { degree }\end{array}$ & $\begin{array}{c}\text { قفزة القطة } \\
\text { Cat jump }\end{array}$ \\
\hline معنوي & 3.24 & 0.3 & 2.03 & 0.5 & 1.75 & $\begin{array}{l}\text { درجة } \\
\text { degree }\end{array}$ & $\begin{array}{c}\text { قفزة المقصنية } \\
\text { scissor jump }\end{array}$ \\
\hline معنوي & 6.16 & 0.48 & 2.4 & 0.38 & 1.9 & $\begin{array}{l}\text { درجة } \\
\text { degree }\end{array}$ & $\begin{array}{c}\text { وثبة الخطوة } \\
\text { The gradient dart }\end{array}$ \\
\hline
\end{tabular}

Among the results presented for the experimental group in Table (7) indicates the presence of significant differences in favor of the post-test, and the researcher attributes the reason for the development of the research sample to the effect of the exercises prepared by the researcher and the extent of its impact and suitability to the abilities of the students, which led to the development of this characteristic because the content of the educational curriculum includes Various exercises focused on developing flexibility, as starting the purposeful early exercise is essential in developing these motor abilities, and despite the difficulties that the researcher faced in the beginning, providing the principle of excitement, creating competition and spreading enthusiasm in the hearts of students had a great impact on overcoming These difficulties, and Osama Kamel points out that the development of "the growth of movement flexibility is affected by the joints of the body by the variables of exercise and movement activity in a more effective way than the variable of age" (1), while the moral differences in the development of the trait of agility confirm the influence and contribution of the educational curriculum in the development of this trait through The lack of performance time and the number of repetitions resulting from the effectiveness of the exercises adopted by the researcher that led to their development, which indicates the validity of the educational curriculum developed by the researcher. 


\section{University of Thi-Qar Journal}

ISSN (print): 2706- 6908, ISSN (online): 2706-6894

Vol.15 No.1 Mar 2020

As well as the development in the above-mentioned differences in the balance characteristic of the post-test results, showing the effectiveness of the curriculum vocabulary and the various movement exercises it contained that helped to develop this trait as well as the researcher's consideration of the principle of competition and repetition for its development. Moreover, the trait of balance develops with training as it improves with increasing age.

And the compatibility test, the results showed that there are statistically significant differences between the pre and post tests in favor of the post test for the experimental group and that these differences are a clear indication of the effect of the approach in developing this trait as well as raising the efficiency and ability of some mental processes for the student by giving her the opportunity to perform movements A harmonic fit with it and with the educational curriculum, as for the cat jump, scissor jump and step jump, the differences shown are clear evidence of the effectiveness of the educational curriculum in developing these skills for the correct selection of exercises used during the curriculum that led to the development of these skills clearly because it provided the opportunity to perform movements There are many harmony in different forms and movements to ensure that the students interact continuously, as it stimulates the spirit of suspense, fun and change from the ordinary. The use of "balls, hoops or other tools for these skills increases the degree of enthusiasm of the pupils and their willingness to practice and perform, and this is the second purpose of the research.

4.1.2 Presentation, analysis and discussion of the results of the test ( $T$ test) for motor abilities and free skills in rhythmic gymnastics for the pre and posttests of the control group: As shown in Table (8) .It shows the arithmetic mean, standard deviations and the calculated value ( $\mathrm{T}$ ) for the pre and posttests of the control group in motor abilities and free skills.

\begin{tabular}{|c|c|c|c|c|c|c|c|}
\hline \multirow[t]{2}{*}{$\begin{array}{c}\text { الدلالة } \\
\text { Indication }\end{array}$} & \multirow{2}{*}{$\begin{array}{c}\text { قالمحسوبة (T) } \\
\text { (The computed } \\
\text { (T) value }\end{array}$} & \multicolumn{2}{|c|}{$\begin{array}{c}\text { الاختبار البعدي } \\
\text { Post-test }\end{array}$} & \multicolumn{2}{|c|}{$\begin{array}{c}\text { الاختبار القبلي } \\
\text { Pre-test }\end{array}$} & \multirow[t]{2}{*}{$\begin{array}{c}\text { وحدة القياس unit } \\
\text { measuring un }\end{array}$} & \multirow[t]{2}{*}{$\begin{array}{l}\text { المتغيرات } \\
\text { Variables }\end{array}$} \\
\hline & & $\begin{array}{l}\varepsilon+ \\
+y\end{array}$ & - س - & $\begin{array}{l}\varepsilon+ \\
+y\end{array}$ & س - س & & \\
\hline $\begin{array}{c}\text { مغنوئ } \\
\text { Significant }\end{array}$ & 3.63 & 2.58 & 3.55 & 2.19 & 2.2 & سم2m & $\begin{array}{c}\text { المرونة } \\
\text { Flexibility }\end{array}$ \\
\hline $\begin{array}{c}\text { منوئ } \\
\text { Significant }\end{array}$ & 5.66 & 7.45 & 13.65 & 1.27 & 15.5 & $\begin{array}{c}\text { ثانية } \\
\text { Second }\end{array}$ & $\begin{array}{l}\text { الرشاقّة } \\
\text { Agility }\end{array}$ \\
\hline معنوي & 4.38 & 2 & 4.9 & 1.82 & 3.5 & ثانية & Balance التوازن \\
\hline
\end{tabular}


ISSN (print): 2706- 6908, ISSN (online): 2706-6894

Vol.15 No.1 Mar 2020

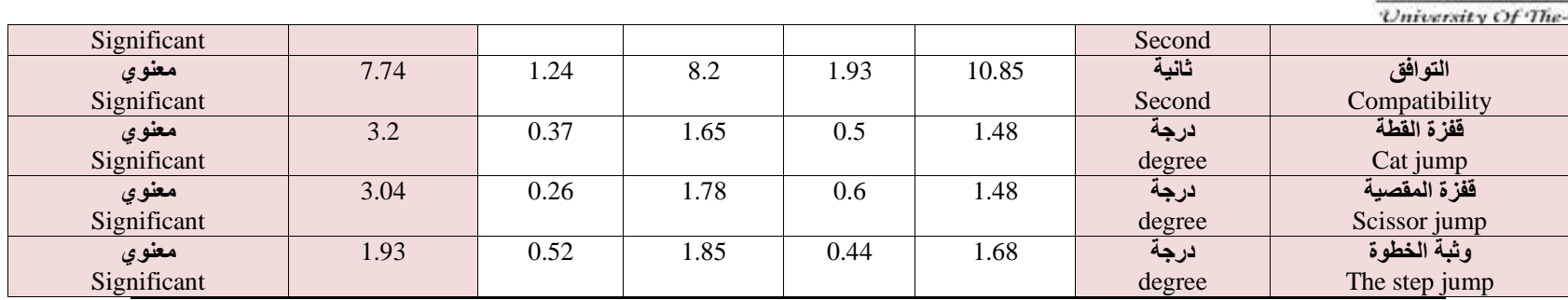

From the results presented to the control group in Table (8), there are significant differences in favor of the post-test.

By presenting the results of the control group in the pre and posttests of motor bilities and free skills, there was a significant impact on the development of each of the ability of flexibility, agility, balance and compatibility, and this is one of the reasons for the development of the learning process and the motivations for learning in addition to the effect and effectiveness of the different exercises and their repetitions that make up the curriculum, And the fact that the gymnastics

\begin{tabular}{|c|c|c|c|c|c|c|c|}
\hline \multirow[t]{2}{*}{$\begin{array}{c}\text { الدلالة } \\
\text { indication }\end{array}$} & \multirow{2}{*}{$\begin{array}{c}\text { المسيوبة } \\
\text { The } \\
\text { computed (T) } \\
\text { value }\end{array}$} & \multicolumn{2}{|c|}{$\begin{array}{l}\text { المــجمو عة الضابطة } \\
\text { Control group }\end{array}$} & \multicolumn{2}{|c|}{$\begin{array}{c}\text { المـــمو عة التجريبية } \\
\text { Experimental group }\end{array}$} & \multirow{2}{*}{$\begin{array}{c}\text { وحدة القياس } \\
\text { measuring } \\
\text { unit }\end{array}$} & \multirow[t]{2}{*}{$\begin{array}{c}\text { المتغير ات } \\
\text { Variables }\end{array}$} \\
\hline & & $\begin{array}{l}\varepsilon+ \\
+\mathbf{y}\end{array}$ & - س & $\begin{array}{l}\varepsilon+ \\
+\mathbf{y}\end{array}$ & - س & & \\
\hline $\begin{array}{c}\text { معنوي } \\
\text { significant }\end{array}$ & 1.96 & 2.58 & 3.55 & 1.67 & 4.9 & سم & $\begin{array}{c}\text { المرونة } \\
\text { Flexibility }\end{array}$ \\
\hline $\begin{array}{c}\text { مeموئificant } \\
\text { significt }\end{array}$ & 2.5 & 7.45 & 13.65 & 0.84 & 13.03 & $\begin{array}{c}\text { ثانية } \\
\text { Second }\end{array}$ & $\begin{array}{l}\text { الرشاقة } \\
\text { Agility }\end{array}$ \\
\hline $\begin{array}{c}\text { معنوي } \\
\text { significant }\end{array}$ & 2.18 & 2 & 4.9 & 2.48 & 6.45 & $\begin{array}{c}\text { ثانية } \\
\text { Second }\end{array}$ & Balance التوازن \\
\hline $\begin{array}{c}\text { معنوي } \\
\text { significant }\end{array}$ & 2.37 & 1.24 & 8.2 & 1.29 & 7.25 & $\begin{array}{c}\text { ثانية } \\
\text { Second }\end{array}$ & $\begin{array}{c}\text { التو افق } \\
\text { Compatibility }\end{array}$ \\
\hline $\begin{array}{c}\text { معنوي } \\
\text { significant }\end{array}$ & 3.62 & 0.37 & 1.65 & 0.23 & 2 & $\begin{array}{c}\text { درجة } \\
\text { degree }\end{array}$ & $\begin{array}{c}\text { قفزة القطة } \\
\text { Cat jump }\end{array}$ \\
\hline $\begin{array}{c}\text { معنوي } \\
\text { significant }\end{array}$ & 2.83 & 0.26 & 1.78 & 0.3 & 2.03 & $\begin{array}{c}\text { درجة } \\
\text { degree }\end{array}$ & $\begin{array}{c}\text { قفزة المقصية } \\
\text { Scissor jump }\end{array}$ \\
\hline $\begin{array}{c}\text { معنوي } \\
\text { significant }\end{array}$ & 3.51 & 0.52 & 1.85 & 0.48 & 2.4 & $\begin{array}{c}\text { درجة } \\
\text { degree }\end{array}$ & $\begin{array}{c}\text { وثبة الخطوة } \\
\text { The step jump }\end{array}$ \\
\hline
\end{tabular}

game was used during the lesson, therefore, it achieved development and effectiveness that led to the raising of the level of the students because it was a game appropriate to their physical abilities.

2) Rissan Khireabet Majeed: Encyclopedia of Measurements and Tests in Physical Education and Sports, Part 1, Basra University, 1989.

They develop according to the repetition associated with tools, explanation, clarification, and movement. "(3) Therefore, the researcher attributes the reason for the development of these capabilities in the control group to those aforementioned reasons. 


\section{University of Thi-Qar Journal}

ISSN (print): 2706- 6908, ISSN (online): 2706-6894

Vol.15 No.1 Mar 2020

4-1-3 Presenting, analyzing and discussing the results of the (T test ) for Movement abilities in the post test of the experimental and control groups. Table (9) It shows the arithmetic mean, standard deviations, and (T) value calculated for the post test of the two experimental and control groups in movement abilities and free skills in rhythmic gymnastics. From the results presented in Table (9) for the dimensional tests and for the experimental and control groups, there is a significant effect on all motor abilities, and this is evident through the differences of the arithmetic mean for the post test of the two groups, as it was found that all the calculated (T) values are greater than the value of $(\mathrm{T})$ The tables and amounts $(1,717)$ and with a degree of freedom (22) and below the level of significance (0.05), which indicates that there are significant differences in favor of the experimental group in all the post tests of motor abilities, thus the proposed approach has proven its effectiveness through the good selection of exercises for motor abilities, and this It indicates the validity of the educational curriculum developed by the researcher, as the effectiveness of the proposed educational curriculum is due to the increase in the number of iterations, which the researcher emphasized, which serves the development of motor abilities, as it gave students a great opportunity to practice the largest possible number of iterations during a single educational unit, as confirmed (Al-Khuli and salary (That "repetition is a basis for learning and determining the number of repetitions of the performance of the movement is an important matter. It depends to a large extent on the teacher's acumen and experience in determining the number of optimal repetitions appropriate for each age stage.") 4), and thus the third purpose of the research is achieved, which is to identify the differences in the level of learning some motor abilities and to learn some free skills in rhythmic gymnastics between the two research groups (experimental and control).

3) Wajeeh Mahjoub, Asya Kadhim: Modern Gymnastics - Rhythmic Mathematical Gymnastics, Baghdad, Dar Al-Hikma Printing and Publishing, 1991, p. 206.

4) Ameen Anwar El-Khouly, Osama Kamel Ratib: Kinetic Education, Cairo, Arab Thought House, 1982, p 151.

\section{Conclusions and recommendations}

\subsection{Conclusions}

According of the research results, the researcher reached the following conclusions:

1- Both approaches have the curriculum prepared by the researcher using the suggested exercises and the approach followed by the subject teacher, have a 


\section{University of Thi-Qar Journal}

ISSN (print): 2706- 6908, ISSN (online): 2706-6894

Vol.15 No.1 Mar 2020

positive and effective effect on developing some movement abilities and learning free skills in rhythmic gymnastics for students.

2- The suggested exercises that were applied to the members of the experimental group contributed clearly and significantly in developing some motor abilities and learning free skills in the rhythmic gymnastics of the students.

3- The results showed a clear and great superiority for the members of the experimental group in the post tests over the control group members in terms of movement abilities and free skills in rhythmic gymnastics.

4- The fun and competitive nature of the exercises proposed by the researcher contributed directly to increasing the desire and motivation to learn among the members of the experimental group.

\subsection{Recommendations:}

Based on the research results, the researcher recommends the following:

1 - Adopting the exercises suggested in the first stage, having a positive and effective effect in developing some movement abilities and free skills in rhythmic gymnastics.

2 - Reconsidering the methodology used in light of the clear results in the development of motor abilities and free skills in rhythmic gymnastics on the control group.

3- Following the same steps that the researcher used to conduct research in other stages that were not covered by the researcher and on other mobility and free skills that were not covered by the researcher.

4- Conducting similar studies for the same school stage to develop physical and mobility capabilities for both sexes and for other sporting activities.

\section{References:}




\section{University of Thi-Qar Journal}

ISSN (print): 2706- 6908, ISSN (online): 2706-6894

Vol.15 No.1 Mar 2020

1. Osama Kamel Ratib: Kinetic Growth, Cairo, Arab Thought House, 1999, 308

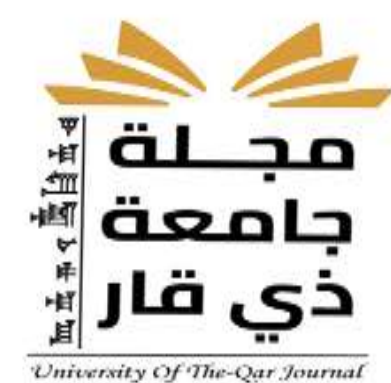

2. Ameen Anwar El-Khouly, Osama Kamel Ratib: Kinetic Education, Cairo, Arab Thought House, 1982, pg 151.

3. Rissan Khireabet Majeed: Encyclopedia of Measurements and Tests in Physical Education and Sports, Part 1, Basra University, 1989.

4. Wajeeh Mahjoub, Asya Kadhim: Modern Gymnastics - Rhythmic Mathematical Gymnastics, Baghdad, Dar Al-Hikma Printing and Publishing, 1991, p. 206. 